\title{
Pengembangan Stadiometer sebagai Alat Ukur Tinggi Badan dan Tinggi Lutut
}

\author{
Sulistyawati \\ Laboratorium Gizi Fakultas Kesehatan Masyarakat Universitas Diponegoro Semarang \\ E-mail : suliswati991@gmail.com
}

Received: $23^{\text {rd }}$ October 2018; Revised: $18^{\text {th }}$ November 2018; Accepted: $19^{\text {th }}$ December 2018; Available online: 16 ${ }^{\text {th }}$ January 2018; Published regularly: January 2019

\begin{abstract}
Anthropometric measurement used to describe the conditions of growth and nutritional status. Linear growth is used to determining height with microtoise several requirements for its installment such as upright wall, flat floor and requires precision to ensure the starting point of measurement at $200 \mathrm{~cm}$ high, which making measurements with this method difficult to guarantee validity in field. This study aimed to make a height measuring instrument more practical, namely the modifiable stadiometer as a measuring instrument for height which can also be used to measure knee height. Material used aluminum to make the tool lighter, practical, and easy to carry. Validity test of tool was using stadiometer Seca 217. Height measurement was performed on 75 subjects in $7^{\text {th }}$ semester students (academic year of 2015/2016) at Faculty of Public Health, University of Diponegoro Semarang. Data were analyzed by using paired t-test at significance level of 0.05 and obtained $p=0.173$. It was concluded that there was no significant difference in measurement results between modifiable stadiometer tool (the design results) and stadiometer Seca 217 , so it can be used as alternative tool for height measurement.
\end{abstract}

Keywords: stadiometer, measuring instrument, height, knee height

\begin{abstract}
Abstrak
Pengukuran antropometri digunakan untuk menggambarkan kondisi pertumbuhan dan status gizi. Pertumbuhan linier salah satunya dapat diketahui melalui pengukuran tinggi badan. Pengukuran tinggi badan selama ini sering menggunakan alat microtoise yang mempunyai beberapa persyaratan dalam cara kerjanya yaitu membutuhkan dinding tegak, lantai datar, dan membutuhkan presisi untuk memastikan titik awal pengukuran pada ketinggian $200 \mathrm{~cm}$, yang membuat pengukuran dengan metode ini sulit untuk menjamin validitas di lapangan. Penelitian ini bertujuan membuat suatu alat ukur tinggi badan yang lebih praktis yaitu stadiometer yang dimodifikasi sebagai alat ukur tinggi badan yang juga dapat digunakan untuk mengukur tinggi lutut. Bahan yang digunakan adalah aluminium sehingga alat tersebut lebih ringan, praktis dan mudah untuk dibawa. Uji validitas alat dilakukan dengan menggunakan stadiometer merk Seca 217. Pengukuran tinggi badan dilakukan pada mahasiswa semester 7 di Fakultas Kesehatan Masyarakat Universitas Diponegoro Tahun Ajaran 2015/2016 sebanyak 75 orang. Data dianalisis dengan menggunakan Paired-Samples T Test pada taraf signifikansi 0,05 dan diperoleh nilai $p=0,173$. Disimpulkan bahwa tidak ada perbedaan yang signifikan hasil pengukuran antara alat stadiometer modifikasi (hasil rancangan) dengan alat stadiometer merk Seca 217 sehingga alat stadiometer modifikasi dapat digunakan sebagai alat alternatif untuk pengukuran tinggi badan.
\end{abstract}

Kata kunci : stadiometer, alat ukur, tinggi badan, tinggi lutut

\section{PENDAHULUAN}

Antropometri ditinjau dari sudut pandang gizi berhubungan dengan berbagai macam pengukuran dimensi tubuh dan komposisi dari berbagai tingkat umur dan tingkat gizi. Ukuran yang sering digunakan 
adalah berat badan dan tinggi badan.(Gibson 2005) Pengukuran antropometri bertujuan untuk mengetahui kondisi pertumbuhan dan status gizi. Pada dasarnya pertumbuhan ada yang bersifat linier dan pertumbuhan massa jaringan. Pertumbuhan linier menggambarkan status gizi yang dihubungkan pada saat lampau. Contoh ukuran linier adalah panjang badan/tinggi badan, lingkar kepala dan lingkar dada. Sedangkan pertumbuhan massa jaringan menggambarkan status gizi yang dihubungkan pada saat sekarang atau saat pengukuran. Contoh ukuran massa jaringan adalah berat badan, lingkar lengan atas dan tebal lemak bawah kulit.(Supariasa et al. 2002) Pertumbuhan linier salah satunya dapat diketahui melalui pengukuran tinggi badan. Tinggi badan atau panjang badan merupakan indikator umum ukuran tubuh dan panjang tulang. Namun, tinggi saja belum dapat dijadikan indikator untuk menilai status gizi, kecuali jika digabungkan dengan indikator lain seperti usia dan berat badan.(Arisman 2010)

Pengukuran antropometri sebenarnya sangat mudah dilakukan namun juga sekaligus rawan terhadap bias dan error data. Untuk menghindari bias dan error data maka hal yang perlu diperhatikan adalah kualitas alat yang digunakan dan ketelitian dalam melakukan pengukuran. Pengukuran tinggi badan selama ini sering menggunakan alat microtoise. Sedangkan untuk memasang microtoise ada beberapa persyaratan, diantaranya membutuhkan dinding yang tegak, lantai datar dan membutuhkan presisi untuk memastikan titik awal pengukuran pada ketinggian $200 \mathrm{~cm}$, yang membuat pengukuran dengan metode ini sulit untuk menjamin validitas di lapangan. Sehingga alat tersebut terkadang kurang efektif apabila digunakan untuk pengambilan data penelitian di lapangan.

Pada orang lanjut usia (lansia) atau orang yang mengalami kelainan tulang dan tidak dapat berdiri tegak, tidak dapat dilakukan pengukuran tinggi badan secara tepat. Menurut Chumlea, bagi lansia yang tidak dapat berdiri ataupun bongkok maka pengukuran tinggi lutut dapat dilakukan untuk memperkirakan tinggi badan.(Chumlea et al. 1998)

Pada penelitian sebelumnya telah dilakukan peneliti tentang pembuatan desain alat ukur tinggi lutut sebagai prediktor tinggi badan lansia. Untuk itu peneliti ingin melakukan pengembangan desain alat ukur berupa stadiometer yang dimodifikasi sebagai alat ukur tinggi badan yang juga dapat digunakan untuk mengukur tinggi lutut, sehingga lebih praktis, efektif dan efisien apabila digunakan untuk penelitian.

Suatu alat ukur dapat dikatakan mempunyai validitas yang tinggi apabila instrumen tersebut menjalankan fungsi ukurnya, atau memberikan hasil ukur yang sesuai dengan maksud dilakukannya pengukuran tersebut.(Machfoedz 2008) Untuk menguji tingkat validitas alat ukur tersebut peneliti juga melakukan pengukuran tinggi badan dengan menggunakan alat yang terstandar (gold standard) yaitu stadiometer merk Seca 217.

\section{BAHAN DAN METODE}

Alat yang digunakan untuk mengukur tinggi badan adalah alat stadiometer modifikasi (hasil rancangan) dan alat stadiometer terstandar (Stadiometer Seca 217). Bahan yang digunakan dalam pembuatan alat stadiometer modifikasi (hasil rancangan) adalah aluminium dan plastik PVC sehingga alat tersebut lebih ringan dan dilengkapi dengan skala ukur berupa mistar/penggaris. Alat ini menggunakan sistem rakitan bongkar pasang sehingga alat tersebut praktis dan mudah dibawa. Selain itu juga dilengkapi alat penyangga untuk membentuk sudut $90^{\circ}$, jika alat akan digunakan untuk mengukur tinggi lutut. Ketelitian alat ukur ini adalah sebesar $0,1 \mathrm{~cm}$.

Pengukuran tinggi badan dilakukan pada mahasiswa semester 7 di Fakultas Kesehatan Masyarakat Universitas Diponegoro Tahun Ajaran 2015/2016. Berdasarkan jumlah perhitungan jumlah sampel minimal 73 orang.(Lemeshow et al. 1990) Pada penelitian ini diperoleh sampel 75 orang.

Data yang telah dikumpulkan, kemudian diolah secara deskriptif. Untuk menentukan uji statistik dilakukan dengan uji normalitas data yaitu menggunakan uji Kolmogorov-Smirnov. Data dianalisis dengan menggunakan Paired-Samples $T$ Test pada taraf signifikansi p=0,05. 


\section{HASIL DAN PEMBAHASAN}

\section{Gambaran Karakteristik Responden}

Responden penelitian ini adalah mahasiswa semester 7 di Fakultas Kesehatan Masyarakat Universitas Diponegoro TA. 2015/2016 yang bersedia untuk menjadi subjek penelitian berjumlah 75 orang. Tabel 1 menunjukkan bahwa sebagian besar responden berumur 21 tahun sebanyak 49 orang (65,3\%). Sedangkan umur terendah adalah 20 tahun sebanyak 19 orang $(25,3 \%)$ dan umur tertinggi adalah 41 tahun sebanyak 1 orang $(1,3 \%)$ yaitu mahasiswa Lintas Jalur.

Tabel 1. Distribusi Frekuensi Umur Responden

\begin{tabular}{ccc}
\hline Umur (tahun) & Jumlah (orang) & Persentase $(\%)$ \\
\hline 20 & 19 & 25,3 \\
21 & 49 & 65,3 \\
22 & 4 & 5,5 \\
29 & 1 & 1,3 \\
40 & 1 & 1,3 \\
41 & 1 & 1,3 \\
\hline Jumlah & 75 & 100,0 \\
\hline
\end{tabular}

Sebagian besar responden adalah perempuan sebanyak 70 orang $(93,3 \%)$ dan laki-laki sebanyak 5 orang (6,7\%), karena sebagian besar mahasiswa Fakultas Kesehatan Masyarakat Universitas Diponegoro adalah perempuan. (Tabel 2)

Tabel 2. Distribusi Frekuensi Jenis Kelamin Responden

\begin{tabular}{ccc}
\hline Jenis Kelamin & Jumlah (orang) & Persentase (\%) \\
\hline Laki-laki & 5 & 6,7 \\
Perempuan & 70 & 93,3 \\
\hline Jumlah & 75 & 100,0 \\
\hline
\end{tabular}

\section{Stadiometer Modifikasi}

Dalam penelitian ini dibuat stadiometer modifikasi yang digunakan untuk mengukur tinggi badan dan juga dapat digunakan untuk mengukur tinggi lutut. Pada saat digunakan untuk mengukur tinggi lutut alat ini dilengkapi dengan alat bantu penyangga kaki bagian lutut supaya membentuk sudut $90^{\circ}$ sesuai dengan prinsip kerja alat yaitu mengukur dimensi secara tegak lurus dengan membentuk sudut $90^{\circ}$. Bahan yang digunakan dari aluminium dan plastik PVC sehingga alat tersebut lebih ringan, praktis dan mudah untuk dibawa. Hasil pengukuran ditunjukkan dengan dengan menggunakan mistar penggaris stainless. Dengan ketelitian alat $0,1 \mathrm{~cm}$. 

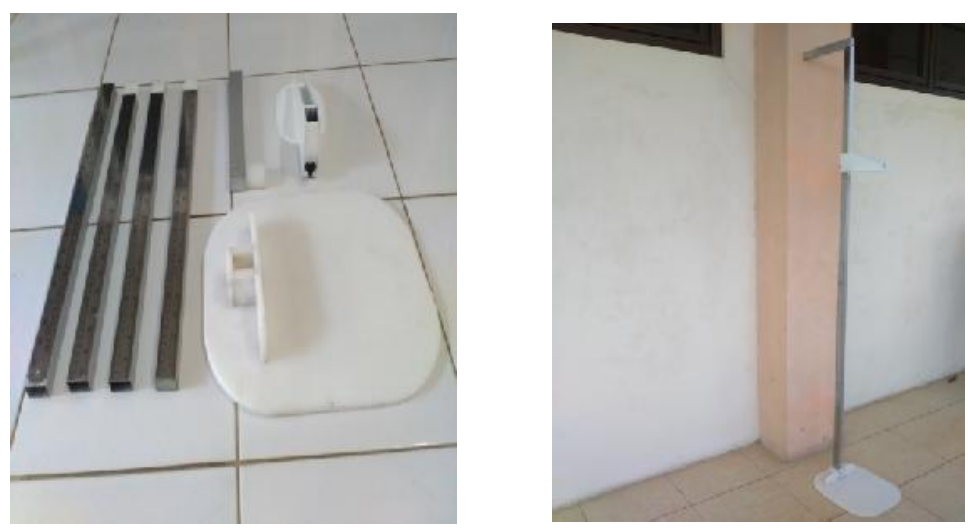

Gambar 1. Alat ukur tinggi badan sederhana (stadiometer sederhana)

Cara pengukuran tinggi badan menggunakan alat stadiometer modifikasi (hasil rancangan) yaitu denga cara memasang rakitan stadiometer sesuai dengan urutan pada lantai yang datar, subjek yang akan diukur melepaskan sepatu, sandal dan topi, kemudian subjek yang akan diukur berdiri tegak, kaki lurus, tumit, pantat, punggung dan kepala bagian belakang harus menempel pada stadiometer dan muka menghadap lurus dengan pandangan ke depan. Menurunkan bagian siku alat sampai rapat pada kepala bagian atas lalu dibaca angka pada skala yang terlihat pada stadiometer. Angka tersebut menunjukkan tinggi subjek yang diukur.
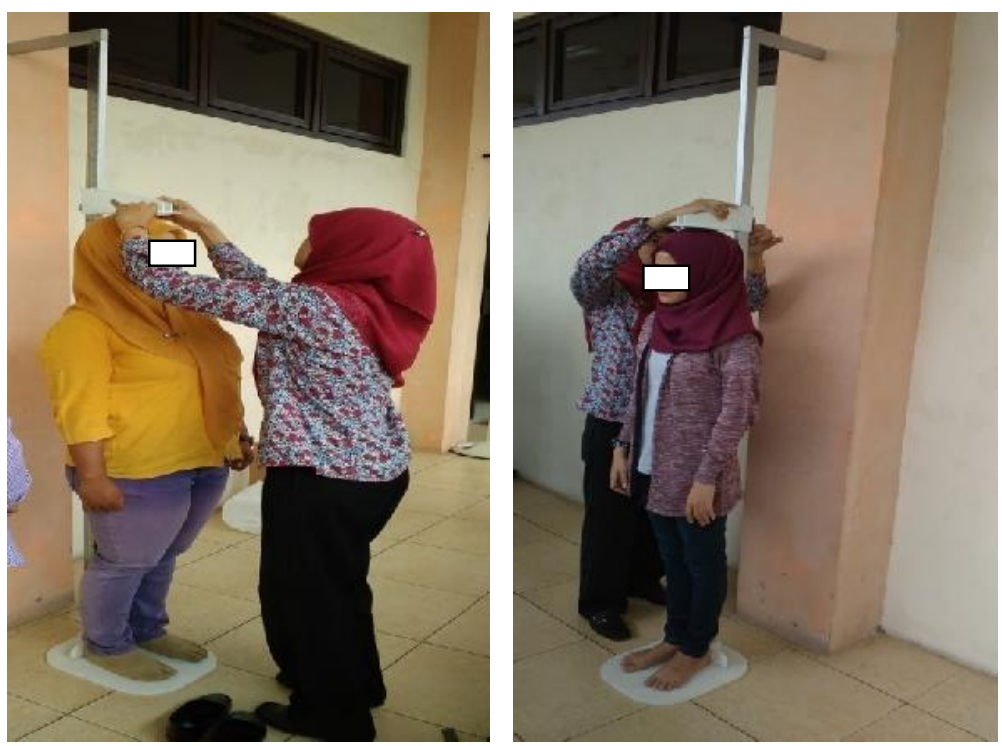

Gambar 2. Cara mengukur tinggi badan dengan stadiometer modifikasi

Apabila alat tersebut akan digunakan untuk mengukur tinggi lutut maka diperlukan alat penyangga kaki bagian lutut supaya membentuk sudut $90^{\circ}$. 

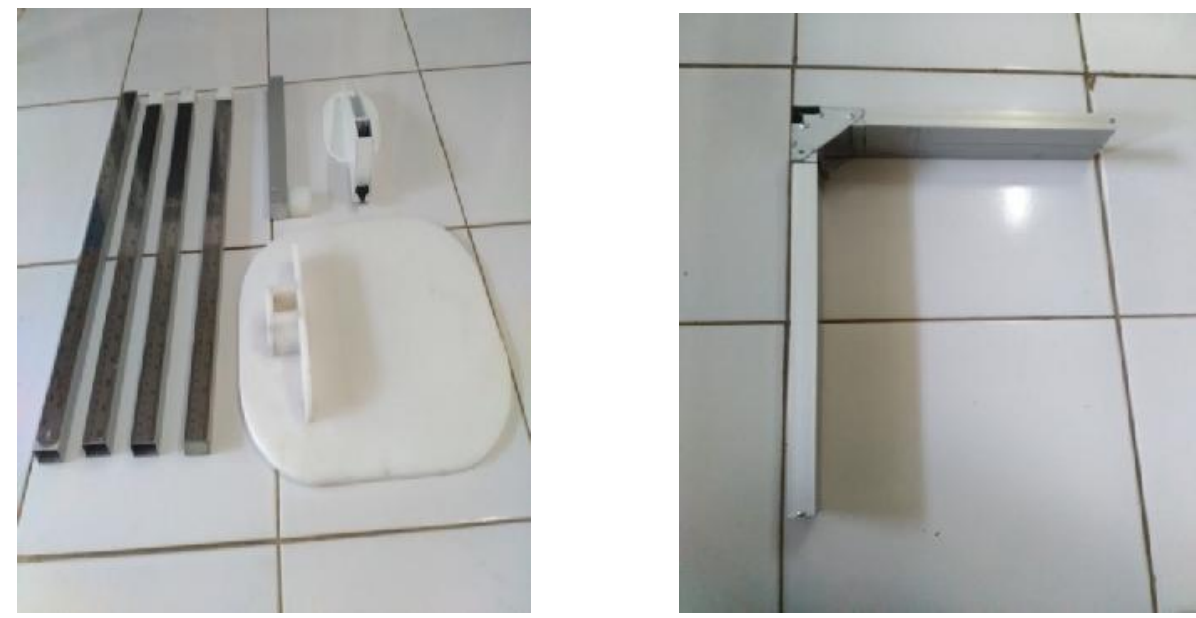

Gambar 3. Alat ukur tinggi badan (stadiometer modifikasi) dilengkapi dengan alat penyangga membentuk sudut $90^{\circ}$

Pengukuran tinggi lutut dilakukan dengan posisi duduk yaitu dengan cara subjek yang diukur ditempatkan dalam posisi duduk di kursi. Pengukuran dilakukan pada kaki kiri subjek antara tulang tibia dengan tulang paha dengan membentuk sudut $90^{\circ}$ dengan dibantu alat penyangga yang diletakkan di bagian bawah paha dan betis. Kemudian alat ukur ditempatkan di antara tumit sampai bagian proksimal dari tulang patella. Menurunkan bagian siku alat sampai rapat dengan bagian lutut, lalu baca angka (tinggi lutut) pada alat secara seksama dan catat angka hasil pengukuran.

Tinggi lutut sangat erat hubungannya dengan tinggi badan sehingga sering digunakan untuk mengestimasi tinggi badan pada subjek dengan gangguan lekukan spinal atau tidak dapat berdiri. Tinggi lutut diukur dengan kaliper berisi mistar pengukuran dengan mata pisau menempel pada sudut $90^{\circ}$. Subjek yang diukur ditempatkan dalam posisi duduk atau berbaring/tidur. Pengukuran dilakukan pada kaki kiri subjek antara tulang tibia dengan tulang paha dengan membentuk sudut $90^{\circ}$. Alat ukurnya ditempatkan diantara tumit sampai bagian proksimal dari tulang patela.(World Health Organization 1995) Menurut penelitian yang dilakukan pada lansia di DKI Jakarta dan Tangerang menunjukkan bahwa tinggi lutut berkorelasi dengan tinggi badan lansia.(Fatmah 2006)
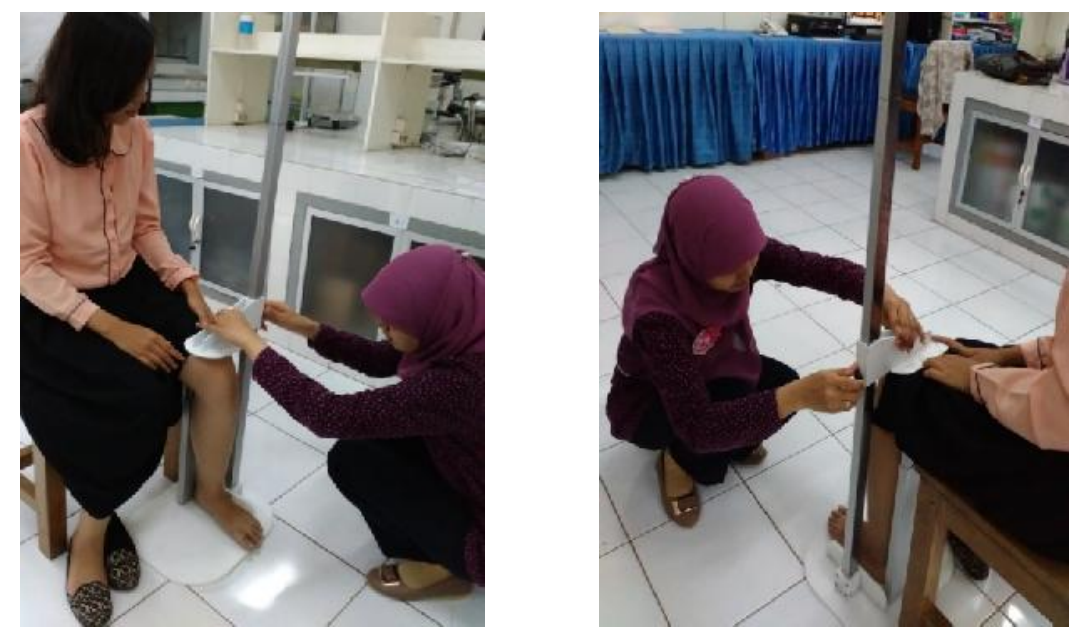

Gambar 4. Cara mengukur tinggi lutut 


\section{Stadiometer merk Seca 217}

Penelitian ini bertujuan untuk mengetahui validitas stadiometer modifikasi sehingga dalam penelitian ini peneliti juga melakukan pengukuran dengan menggunakan alat ukur standar. Alat ukur tinggi badan standar yang digunakan adalah stadiometer merk Seca 217 dengan ketelitian 0,1 cm. Oleh karena itu peneliti menggunakan alat ini sebagai pembanding dalam penelitian untuk menguji validitas alat.

Pengukuran dengan menggunakan stadiometer merk Seca 217 yaitu dengan cara memasang bagian batang stadiometer secara urut sesuai dengan kode gambar yang tertera pada dasar alat, pasang bagian batang pertama dan kedua, kemudian masukkan bagian penunjuk skala pada batang stadiometer yang kedua, selanjutnya pasang batang stadiometer yang ketiga dan keempat.Memasang bagian penyangga untuk membantu stadiometer agar tegak lurus membentuk sudut $90^{\circ}$. Meletakkan stadiometer pada tempat yang datar dan dinding yang lurus. Subjek yang akan diukur melepaskan topi, sepatu atau sandal. Subjek yang akan diukur berdiri tegak, kaki lurus, tumit, pantat, punggung dan kepala bagian belakang harus menempel pada batang stadiometer dan muka menghadap lurus dengan pandangan ke depan. Turunkan bagian penunjuk skala sampai rapat pada kepala bagian atas, kemudian baca angka yang terlihat pada lubang dalam bagian penunjuk skala. Angka tersebut menunjukkan tinggi subjek yang diukur.
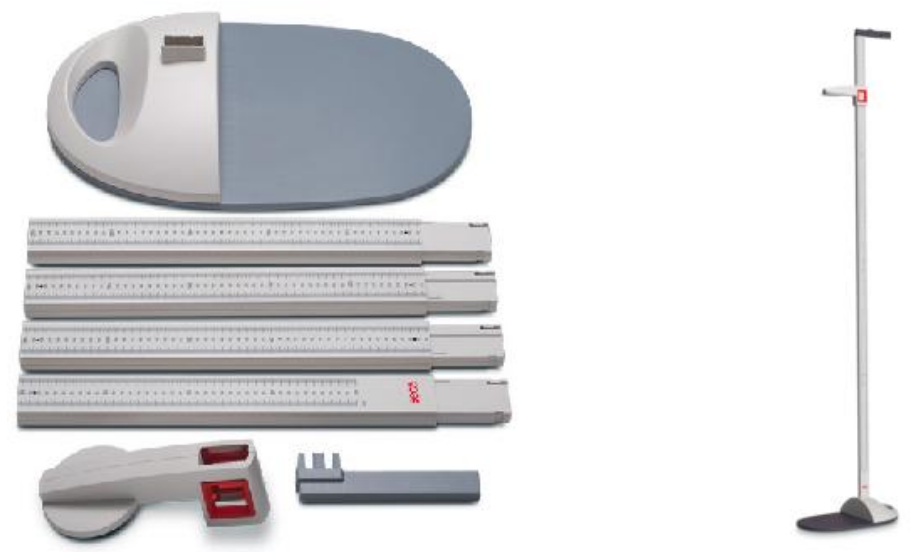

Gambar 5. Alat stadiometer merk Seca 217 (Anon n.d.) 

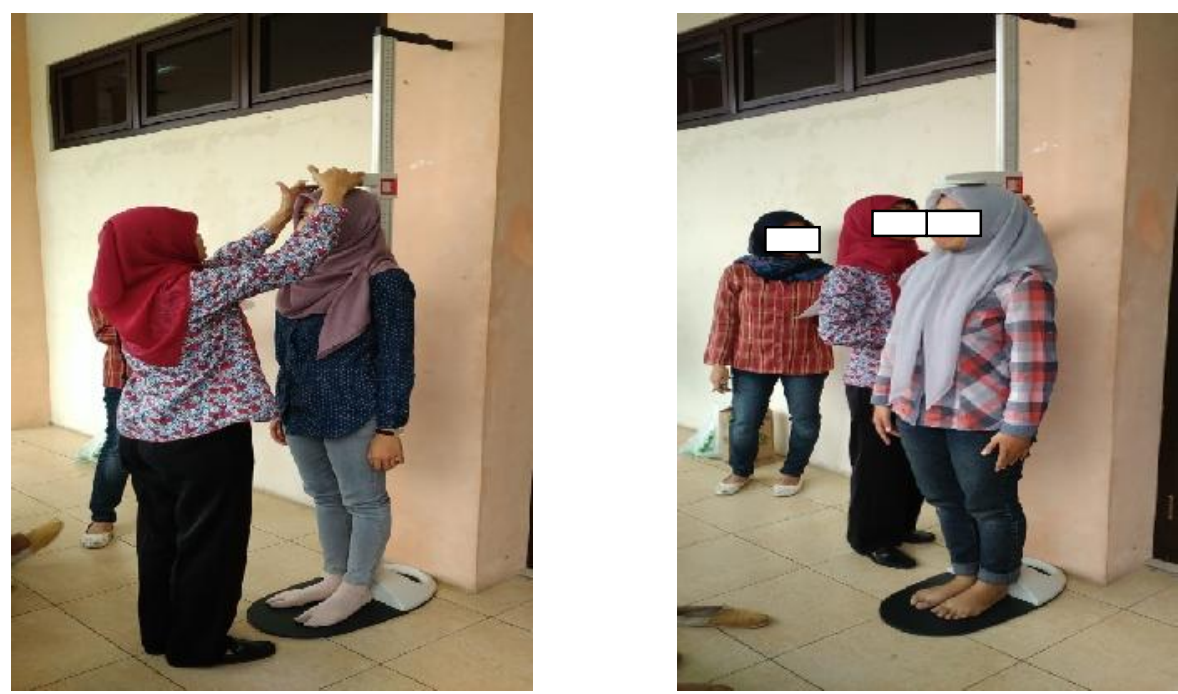

Gambar 6. Cara mengukur tinggi badan dengan stadiometer merk Seca 217

\section{Pengukuran tinggi badan responden dengan menggunakan stadiometer modifikasi dan stadiometer merk Seca 217}

Pengukuran tinggi badan dengan alat stadiometer modifikasi diperoleh nilai minimum tinggi badan adalah 144,80 cm dan nilai maksimum adalah $173,40 \mathrm{~cm}$. Sedangkan pengukuran dengan menggunakan alat stadiometer merk Seca 217 diperoleh nilai minimum tinggi badan adalah 144,90 cm dan nilai maksimum adalah 173,60 $\mathrm{cm}$. Rerata tinggi badan responden yang diukur dengan alat stadiometer modifikasi adalah 156,08 $\pm 5,13$ tidak jauh berbeda dengan hasil pengukuran tinggi badan dengan alat stadiometer merk Seca 217 adalah 156,12 \pm 5,12.

Tabel 3. Rerata Tinggi Badan Responden

\begin{tabular}{lcccc}
\hline \multicolumn{1}{c}{ Variabel } & $\mathrm{n}$ & Min & Maks & Rerata \pm SB \\
\hline Tinggi badan dengan alat stadiometer sederhana & 75 & 144,8 & 173,40 & $156,08 \pm 5,13$ \\
Tinggi badan dengan alat stadiometer merk Seca 217 & 75 & 144,90 & 173,60 & $156,12 \pm 5,12$ \\
\hline
\end{tabular}

Tinggi badan dan berat badan merupakan parameter untuk memperkirakan kebutuhan zat gizi dan untuk mengukur Indeks Massa Tubuh (IMT). IMT merupakan ukuran antropometri yang seringkali digunakan untuk menentukan status gizi seseorang.

Tabel 4. Indeks Massa Tubuh (IMT) Responden

\begin{tabular}{lcccc}
\hline \multicolumn{1}{c}{ Variabel } & $\mathrm{n}$ & Min & Maks & Rerata \pm SB \\
\hline IMT dengan alat stadiometer modifikasi & 75 & 16,30 & 36,64 & $22,07 \pm 4,37$ \\
IMT dengan alat stadiometer merk Seca 217 & 75 & 16,30 & 36,64 & $22,06 \pm 4,36$ \\
\hline
\end{tabular}

Rerata Indeks Massa Tubuh (IMT) dari hasil penghitungan berat badan dibagi tinggi badan dalam meter kuadrat dengan alat stadiometer modifikasi adalah 22,07 $\pm 4,37$ tidak jauh berbeda dengan hasil pengukuran tinggi badan dengan alat stadiometer merk Seca 217 adalah 22,06 4,36. (Tabel 4) 


\section{Validitas alat stadiometer modifikasi terhadap alat stadiometer merk Seca 217}

Tinggi badan atau panjang badan merupakan indikator umum ukuran tubuh dan panjang tulang. Namun, tinggi saja belum dapat dijadikan indikator untuk menilai status gizi, kecuali jika digabungkan dengan indikator lain seperti usia dan berat badan. Tinggi badan diperlukan dalam pengukuran status gizi seseorang.

Validitas alat ukur sangat diperlukan dalam penelitian untuk mendapatkan hasil yang tepat dan akurat. Analisis data hasil pengukuran diuji dengan menggunakan Paired-Samples $T$ Test pada taraf signifikansi 0,05 diperoleh nilai $p$-value $=0,173$ dan hasil penghitungan IMT juga diperoleh nilai $p$-value $=0,104$ artinya tidak ada perbedaan hasil pengukuran antara alat stadiometer modifikasi (hasil rancangan) dengan alat stadiometer merk Seca 217. (Tabel 5)

Tabel 5.Uji beda alat stadiometer sederhana terhadap alat stadiometer merk Seca 217 standar

\begin{tabular}{lccc}
\hline & Alat stadiometer sederhana & Alat stadiometer merk Seca 217 & $p$ value \\
\hline Tinggi badan * & $156,08 \pm 5,13$ & $156,12 \pm 5,12$ & 0,173 \\
\hline IMT $*$ & $22,07 \pm 4,37$ & $22,06 \pm 4,36$ & 0,104 \\
\hline
\end{tabular}

$*(\mathrm{p}<0,05$, Paired-Samples T Test $)$

\section{KESIMPULAN}

Tidak ada perbedaan yang signifikan hasil pengukuran antara alat stadiometer modifikasi (hasil rancangan) dengan alat stadiometer merk Seca 217 sehingga alat stadiometer modifikasi dapat digunakan sebagai alat alternatif untuk pengukuran tinggi badan.

\section{UCAPAN TERIMA KASIH}

Ucapan terima kasih kepada Fakultas Kesehatan Masyarakat Universitas Diponegoro yang telah membantu dalam pembiayaan penelitian ini, enumerator ( Indah, Eni, Wisnu) dan semua reponden yang telah membantu dalam penelitian ini.

\section{DAFTAR PUSTAKA}

Anon, The Mobile Stadiometer Seca 217. Available at: https://www.seca.com/en_bb/products/allproducts/product-details/seca217.html.

Arisman, 2010. Gizi dalam Daur Kehidupan 2nd ed., Jakarta: Buku Kedokteran EGC.

Chumlea, C. et al., 1998. Stature Prediction Equations for Elderly non-Hispanic White, non-Hispanic Black and Mexican-American Persons Developed from NHANES III Data. Journal of the American Dietetic Association, 98(2), pp.137-142.

Fatmah, 2006. Persamaa (Equation) Tinggi Badan Manusia Usia Lanjut (Manula) berdasarkan Usia dan Etnis pada 6 Panti Terpilih di DKI Jakarta dan Tangerang Tahun 2005. Makara Kesehatan, 10(1), pp.7-16.

Gibson, R., 2005. Principles of Nutritional Assesment, New York: Oxford University.

Lemeshow, S. et al., 1990. Adequacy of Sample Size in Health Studies, Chichester, New York, Brisbane, Toronto, Singapore: World Health Organization by John Wiley \& Sons.

Machfoedz, I., 2008. Teknik Membuat Alat Ukur Penelitian Bidang Kesehatan, Kedokteran, Keperawatan dan Kebidanan, Yogyakarta: Fitramaya.

Supariasa, I.D.N., Bakri, B. \& Fajar, I., 2002. Penilaian Status Gizi, Jakarta: Buku Kedokteran EGC.

World Health Organization, 1995. Physical Status: The Use and Interpretation of Anthropometry. Report of a WHO Expert Committee. 
JPLP Jurnal Pengelolaan Laboratorium Pendidikan, 1 (1) 2019

Copyright @ 2019, JPLP, e ISSN 2654-251X 